\title{
Adversity Quotient, Komitmen Organisasi dan Kesiapan Untuk Berubah Dalam Meningkatan Kinerja Karyawan di Masa Pandemi Covid-19
}

\author{
Harry Theozard Fikri, Rika Wahyuni, Isna Asyri Syahrina, Frihapma Semita Ade, \\ Rina Mariana
}

\author{
Fakultas Psikologi Universitas Putra Indonesia Yptk Padang \\ email: rikawahyuni070685@gmail.com
}

\begin{abstract}
Abstrak
Artikel INFO

Diterima:17 Maret 2021

Direvisi 20 Agustus2021

Disetujui:23 September 2021

DOI:

http://dx.doi.org/10.24014/

jp.v14i2.12556

Optimalisasi kinerja karyawan sangat penting sebagai upaya agar usaha dapat beroperasi dan bertahan pada situasi pandemi Covid-19. Jika karyawan memiliki kinerja yang tinggi, partisipasinya terhadap jalannya sebuah usaha cenderung akan tinggi. Tujuan dilakukannya penelitian ini adalah menguji pengaruh antara adversity quotient, komitmen organisasi dan kesiapan untuk berubah terhadap kinerja karyawan Swalayan di Kota Padang. 108 karyawan Swalayan di Kota Padang menjadi sampel penelitian dengan metode purposive sampling. Data dikumpulkan menggunakan kuesioner adversity quotient, komitmen organisasi, kesiapan untuk berubah dan kinerja karyawan. Hasil penelitian menunjukkan bahwa terdapat pengaruh adversity quotient, komitmen organisasi dan kesiapan untuk berubah terhadap kinerja karyawan. Hasil penelitian juga menunjukkan bahwa terdapat pengaruh positif dan signifikan antara adversity quotient terhadap kinerja karyawan $\mathrm{H}_{1}$ diterima. Terdapat pula pengaruh positif dan signifikan antara komitmen organisasi terhadap kinerja karyawan $\mathrm{H}_{2}$ diterima. Hasil penelitian ketiga terbukti bahwa terdapat pengaruh positif dan signifikan antara kesiapan untuk berubah terhadap kinerja karyawan $\mathrm{H}_{3}$ diterima. Analisis data memakai metode Multiple Linear Regression dengan IBM SPSS Statistics 23 for Windows. Implikasi dari temuan penelitian ini yaitu karyawan harus memiliki adversity quotient, komitmen organisasi dan kesiapan untuk berubah pada situasi pandemi Covid-19 untuk mengoptimalkan kinerja mereka.
\end{abstract}

Kata kunci: adversity Quotient; komitmen organisasi; kesiapan untuk berubah; kinerja karyawan

\section{Adversity Quotient, Organizational Commitment And Readiness To Change In Improving Employee Performanceln The Pandemic Time Covid-19}

\begin{abstract}
Optimizing employee performance is meaningful and must be tried in an effort so that businesses can always survive the situation Covid-19 pandemic. If employees have high performance, their participation in the running of a business tends to be high. The purpose of this study was to examine and determine the effect of adversity quotient, organizational commitment and readiness to change on supermarkets employees' performance in Padang City. There are 108 supermarket employees in Padang city with a purposive sampling method. The research data were collected using a questionnaire adversity quotient, organizational commitment, readiness to change and employee performance. The results showed that there was an influence between adversity quotient, organizational commitment and readiness to change on employee performance. The results also show that there is a positive and significant influence between adversity quotients on employee performance $\mathrm{H}_{1}$ is accepted. There is a positive and significant influence between organizational commitment on employee performance $\mathrm{H}_{2}$ is accepted. The results of the third study proved that there is a positive and significant influence between readiness to change on employee performance $\mathrm{H}_{3}$ is accepted. Data were analyzed using Multiple Linear Regression with IBM SPSS Statistics 23 for Windows. The implication of this result is that employees should be aware about the adversity quotient, organizational commitment and readiness to change in improving the situation Covid-19 pandemic in order to optimize the employee performance.
\end{abstract}

Keywords: adversity quotient; organizational commitment; readiness for change; employee performance 


\section{Pendahuluan}

Secara global pandemi Covid-19 menimbulkan penyusutan perekonomian Negara serta perekonomian masyarakat. Proyeksi ekonomi global bagi IMF berkembang minus pada angka 3\% (Thaha, 2020), dimana Indonesia diproyeksikan hadapi penyusutan ekonomi sebesar $5-5,4 \%$ dari $5,1-5,5 \%$ (Rohmah \& Syari, 2020). Dampak virus corona nyaris dirasakan oleh segala bidang usaha (Meilina \& Sardanto, 2020), termasuk usaha swalayan. Sebagai pusat perbelanjaan modern yang menyediakan serta menjual beberapa barang kebutuhan masyarakat, swalayan berpotensi besar menjadi sarana penyebaran Covid-19.

Seperti yang dilansir kompas.com, terdata seorang karyawan Swalayan di Kota Bogor positif terpapar virus corona. Tidak cuma itu, 2 orang karyawan swalayan di Kota Padang Panjang juga dinyatakan positif terinfeksi corona serta berkemungkinan daerah lainnya seperti Kota Padang yang terdapat banyak swalayan, karyawannya berisiko tinggi tertular virus corona saat bekerja. Sebelum pandemi Covid-19, swalayan di Kota Padang selalu ramai dengan pengunjung dengan layanan yang diberikan karyawan tetap baik. Setelah terjadinya pandemi Covid-19 pengunjung swalayan sangat berkurang, sehingga pemilik swalayan wajib membuat kebijakan untuk menjaga keselamatan karyawan maupun pelanggan dengan menerapkan protokol kesehatan dalam aktivitas bisnisnya agar pengunjung tetap merasa aman dan nyaman saat berbelanja. Tetapi, tingginya efek tersebut tidak diiringi dengan kepatuhan karyawan saat bekerja. Praktek protokol kesehatan seperti memakai masker, cuci tangan dan menjaga kebersihan swalayan belum dilaksanakan dengan baik oleh karyawan.

Pergantian kebiasaan sepanjang pandemi tidak begitu saja langsung bisa diterima oleh karyawan sehingga berpengaruh pada kinerja karyawan. Terdapat rasa khawatir ataupun takut dalam melaksanakan pekerjaan sehari-hari berakibat pada Psikologis yang mengganggu aktivitas pekerjaan sehingga membuat hasil kerja tidak optimal. (Bacal, 2015) menyatakan kinerja merupakan kontribusi karyawan atas tujuan pekerjaan/ unit kerja dan organisasi selaku hasil perilaku serta aplikasi dari keterampilan, kemampuan dan pengetahuannya. Fattah (2017) menyatakan kinerja merupakan unjuk kerja penerapan tugas karyawan yang menjadi tanggung jawabnya. Tugas tersebut bersumber dari keberhasilan karyawan. Pendapat Abdullah (2014) kinerja merupakan hasil kerja individu yang terpaut dengan strategi organisasi, kepuasan pelanggan dan ekonomi. Kinerja seseorang tergambar dari capaian atas pelaksanaan program kegiatan maupun kebijakan untuk mewujudkan tujuan, sasaran, visi misi organisasi dalam rencana strategis (Moeheriono, 2012).

Mathis \& Jackson (2015) mengemukakan adanya lima indikator kinerja karyawan, yaitu (1) kuantitas (quantity of work), yaitu volume kerja yang dapat dihasilkan karyawan pada saat kondisi normal; (2) kualitas (quality of work), yaitu hasil kerja karyawan yang mendekati sempurna atau sesuai dengan tujuan yang diharapkan perusahaan; (3) ketepatan waktu (timeline of work), yaitu kemampuan karyawan menyelesaikan aktivitas pekerjaannya sesuai waktu yang ditetapkan perusahaan; (4) kehadiran (attendance), yaitu tingkat hadirnya karyawan di perusahaan; dan (5) kerjasama (ability to cooperate), yaitu kemampuan yang dimiliki karyawan dalam menangani hubungan dengan rekan kerja maupun atasan dalam pekerjaan.

Kinerja karyawan dipengaruhi banyak faktor antara lain seperti budaya organisasi, motivasi dan komitmen organisasi (Ariyanto et al., 2019), etika kerja dan adversity quotient (Runtu et al., 2019), budaya organisasi, komitmen organisasi dan kepuasan kerja (Paramita et al., 2020). Kinerja karyawan juga 
dipengaruhi oleh kesiapan buat berubah dan kepemimpinan transformasional (Novitasari et al., 2020), kepuasan kerja, komitmen organisasi serta OCB (Kristian \& Ferijani, 2020). Faktor-faktor yang mempengaruhi kinerja karyawan pada penelitian ini adalah adversity quotient, komitmen organisasi, dan kesiapan untuk berubah.

Adversity quotient berperan penting bagi karyawan untuk meningkatkan kinerjanya (Runtu et al., 2019).Adversity quotient menurut Stoltz (2005) adalah wujud kecerdasan yang melatarbelakangi keberhasilan seseorang saat menghadapi tantangan dan kesusahan. Dengan kata lain, adversity quotient dapat membantu individu menguatkan kemampuan dan ketekunannya dalam menghadapi tantangan kehidupan sehari-hari (Ablaña et al., 2016).

Stoltz (2005) mengemukakan bahwa adanya empat dimensi adversity quotient yaitu (1) kendali (core), yaitu kemampuan individu memberi pengaruh serta mengendalikan respon dengan positif terhadap situasi apapun; (2) asal usul dan pengakuan (origin dan ownership), yaitu kemampuan individu mempertanggung jawabkan akibat dari situasi yang ada tanpa mempermasalahkan penyebabnya; (3) daya jangkauan (reach), yaitu kemampuan individu membiarkan kesulitannya menjangkau bidang lain pada pekerjaan dan di dalam kehidupannya; dan (4) daya tahan menghadapi kesulitan (endurance), yaitu persepsi individu tentang berapa lama kesulitan yang ada akan berlangsung.

Kondisi karyawan swalayan jika dihubungkan dengan situasi pandemi Covid-19 saat ini, ternyata dapat dipahami tidak optimalnya kinerja salah satunya disebabkan oleh rasa sulit dan rasa tidak percaya diri dalam mengatasi masalah, maka dari itu adversity quotient yang baik menjadi penting agar karyawan dapat mengontrol perasaan frustasi dan cemas terkena Covid-19 saat bekerja.
Dari hasil kajian penelitian sebelumnya, beberapa penelitian menunjukkan bahwa adversity quotient mempengaruhi kinerja. Salah satu hasil riset dilakukan oleh Lubis (2019). Hasil penelitiannya menunjukkan bahwa adversity quotient berpengaruh positif dan signifikan terhadap kinerja, sedangkan penelitian yang dilakukan oleh (Irawan \& Yulihasri, 2019) juga membuktikan bahwa salah satu faktor yang mempengaruhi kinerja adalah adversity quotient. Penelitian yang dilakukan (Phoolka \& Kaur, 2012). Hasil penelitiannya menunjukkan bahwa adversity quotient berpengaruh positif terhadap kinerja karyawan, karena kemampuan individu mengatasi situasi sulit yang dihadapinya akan berdampak pada peningkatan kinerjanya di perusahaan.

Selain adversity quotient, kinerja karyawan juga dipengaruhi beberapa faktor lainnya, yaitu komitmen organisasi (Rais et al., 2016), dengan kata lain kinerja akan meningkat apabila dilakukannya perbaikan komitmen organisasi pada karyawan. Meyer \& Allen (1997) mengemukakan bahwa Komitmen organisasi adalah konstruk psikologis selaku ciri dari ikatan anggota organisasi dengan organisasinya yang kemudian berimplikasi terhadap keputusan individu untuk melanjutkan keberadaannya selaku anggota dalam organisasi.

Komitmen organisasi memiliki tiga komponen yaitu (1) komitmen afektif, yaitu bentuk kelekatan emosi karyawan, identifikasi dirinya dan memperlihatkan keterlibatannya di dalam perusahaan; (2) komitmen normatif, yaitu kesadaran karyawan akan kerugian yang akan dialaminya apabila ia tidak lagi bekerja di perusahaan; dan (3) komitmen berkelanjutan, yaitu perasaan karyawan atas kewajibannya untuk selalu mengerjakan pekerjaan (Meyer \& Allen (1997). Hasil survey awal kepada 30 orang karyawan swalayan di kota Padang disimpulkan bahwa komitmen organisasi karyawan masih tergolong rendah. $43 \%$ karyawan setuju untuk bertahan dalam 
kondisi Covid-19 walaupun ada tawaran pekerjaan lain sedangkan $57 \%$ tidak setuju. Selanjutnya, $36 \%$ karyawan setuju memiliki kewajiban untuk tetap bekerja di swalayan selama pandemi Covid-19 sedangkan 64\% tidak setuju.

Berdasarkan hasil riset sebelumnya, beberapa penelitian menunjukkan bahwa komitmen organisasi mempengaruhi kinerja. Salah satu hasil riset dilakukan oleh Kristian \& Ferijani (2020) kepada 52 orang karyawan PT. Ulam Tiba Halim Distributor Company. Hasilnya menunjukkan adanya pengaruh positif dan signifikan komitmen organisasi terhadap kinerja, semakin tinggi komitmen organisasi akan meningkatkan kinerja karyawan, sedangkan penelitian yang dilakukan (Hendri, 2019), juga membuktikan faktor yang mempengaruhi kinerja karyawan adalah komitmen organisasi. Hasil menunjukkan komitmen organisasi secara signifikan berpengaruh terhadap kinerja.

Kesiapan untuk berubah merupakan faktor yang mempengaruhi kinerja (Kamar et al., 2020). Organisasi harus mulai melakukan strategi untuk berubah dengan mempersiapkan sumber daya manusia yang akan menerima perubahan karena manusia adalah subjek atau objek dalam perubahan tersebut dan memiliki sifat resisten atas perubahan (Wibowo, 2012).

Kesiapan untuk berubah adalah sikap komprehensif individu dipengaruhi oleh konten/isi perubahan, proses perubahan, konteks perubahan dan atribut individu yang secara bersama tercermin pada aspek kognitif maupun emosional yang terlihat dari kecenderungan individu menerima, menganut dan mengadopsi perubahan untuk mengganti kondisi saat ini (Holt et al., 2007). Pada kondisi pandemi Covid-19 yang terjadi di dunia termasuk di Indonesia, meniscayakan adanya perubahan situasi dan kondisi pada bisnis dimasa ini (Asbari et al., 2020). Hasil observasi ditemukan terdapat karyawan yang sulit beradaptasi dengan sistem kerja baru yang sesuai dengan aturan Pemerintah yakni penerapan protokol kesehatan, diantaranya: 1) saat melayani pelanggan masih ada karyawan yang melepaskan masker, 2) tidak memakai face shield dan sarung tangan, dan 3) social distancing belum dijalankan secara baik oleh karyawan.

Holt et al., (2007) mengemukakan adanya empat dimensi yang mampu merubah keyakinan karyawan untuk melakukan perubahan yaitu (1) appropriateness, yaitu keyakinan bahwa perubahan spesifik yang diajukan adalah cara tepat bagi organisasi untuk mengatasi permasalahan yang terjadi; (2) change efficacy, yaitu rasa kepercayaan bahwa karyawan dan organisasi mampu mengimplementasikan perubahan; management support, yaitu persepsi karyawan bahwa organisasi memberikan dukungan dan memiliki komitmen dalam mensukseskan perubahan; dan (4) personal valence, yaitu keyakinan karyawan bahwa perubahan akan memberikan manfaat atau keuntungan personal bagi karyawan.

Beberapa hasil riset sebelumnya, menunjukkan bahwa kesiapan untuk berubah mempengaruhi kinerja, terbukti melalui penelitian yang dilakukan oleh Novitasari dkk (2020) pada 224 karyawan di industri HVAC di Tangerang yang menunjukkan terdapatnya pengaruh positif dan signifikan kesiapan untuk berubah terhadap kinerja karyawan. Selain itu, penelitian lain yang dilakukan oleh Banjongprasert (2017); Katsaros et al., (2020) menunjukkan terdapat pengaruh positif dan signifikan kesiapan untuk berubah terhadap kinerja.

Kinerja karyawan penting untuk diteliti lebih lanjut, karena kinerja karyawan yang optimal akan mengikuti hasil yang baik serta berdampak pada keberhasilan usaha. Penelitian ini bertujuan untuk menguji pengaruh adversity quotient, komitmen organisasi dan kesiapan untuk berubah terhadap kinerja karyawan. 


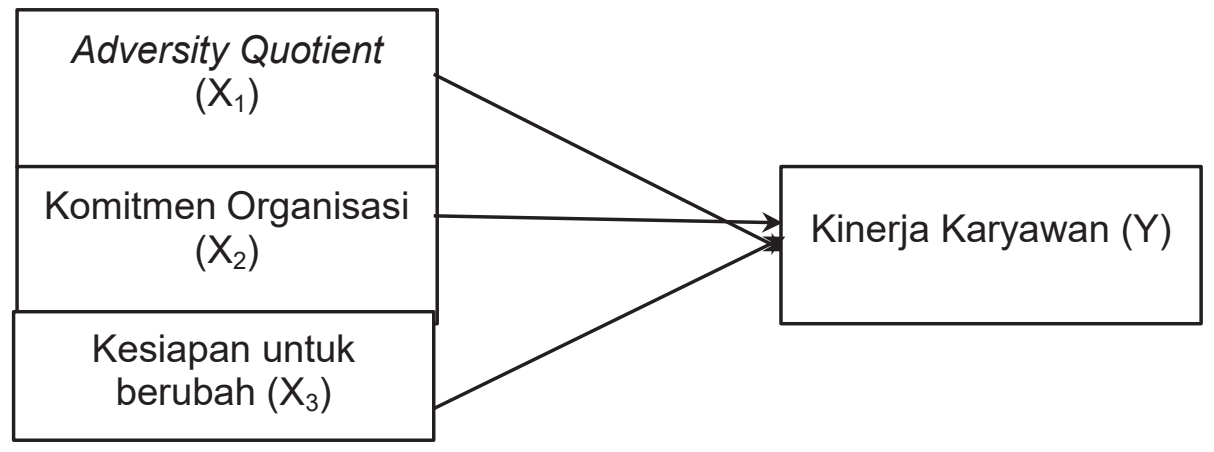

Gambar 1. Alur Hipotesis Penelitian

\section{Metode}

\section{Desain Penelitian dan Partisipan}

Penelitian ini akan menguji tiga hipotesis yang merupakan penelitian kuantitatif yaitu penelitian yang menekankan analisisnya pada data numerik atau angka yang selanjutnya dilakukan pengolahan data melalui metode statistika (Azwar, 2015). Penelitian ini termasuk dalam jenis penelitian kausal, karena variabel satu dengan variabel lainnya saling berhubungan. Penelitian melibatkan

\section{Pengukuran}

Alat ukur menggunakan kuesioner model skala likert. Alat ukur adversity quotient terdiri dari empat dimensi yaitu (1) kendali (core), (2) asal usul dan pengakuan (origin dan ownership), (3) daya jangkauan (reach), dan (4) daya tahan menghadapi kesulitan (endurance) (Stoltz, 2005). Uji validitas pada penelitian menggunakan perbandingan nilai $r$-hitung > r-tabel (corrected item total correlation) dengan derajat kepercayaan sebesar 95\% ( $\alpha=5 \%$ ) dengan nilai r-tabel $=0,361$. Hasil uji validitas adversity quotient mempunyai koefisien korelasi item-item pernyataan lebih besar dari $r$-tabel $=0,361$, maka item-item pernyataan adalah valid. Pengujian reliabilitas menggunakan Cronbach Alpha ( $\alpha$ ). Cronbach Alpha adversity quotient sebesar 0,888, ini menandakan instrumen penelitian reliabel dan item-item pernyataan memiliki kelayakan untuk dijadikan alat ukur penelitian.
4 variabel yakni variabel terikat $(Y)$ kinerja karyawan, variabel bebas $\mathrm{X}_{1}$ adalah adversity quotient, komitmen organisasi $\left(\mathrm{X}_{2}\right)$ dan kesiapan untuk berubah $\left(\mathrm{X}_{3}\right)$. Teknik sampel penelitian adalah purposive sampling dengan karakteristik sampel yaitu karyawan yang bekerja lebih dari 1 tahun karena dianggap lebih mengetahui dengan baik kondisi swalayan. Dengan menggunakan purposive sampling, maka populasi penelitian adalah seluruh karyawan swalayan di Kota Padang, serta ada 108 orang sampel penelitian.

Komitmenorganisasidiukurmenggunakan tiga komponen yang dikemukakan Meyer \& Allen (1997) yaitu (1) komitmen afektif, (2) komitmen normatif, dan (3) komitmen berkelanjutan. Uji validitas pada penelitian menggunakan perbandingan nilai r-hitung $>$ r-tabel (corrected item total correlation) dengan derajat kepercayaan sebesar 95\% $(\alpha=5 \%)$ dengan nilai $r$-tabel $=0,361$. Hasil uji validitas komitmen organisasi mempunyai koefisien korelasi item-item pernyataan lebih besar dari r-tabel $=0,361$, maka itemitem pernyataan adalah valid. Pengujian reliabilitas menggunakan Cronbach Alpha (a). Pada kuesioner komitmen organisasi nilai Cronbach Alpha sebesar 0,844, ini menandakan instrumen penelitian reliabel dan item-item pernyataan memiliki kelayakan untuk dijadikan alat ukur penelitian.

Kuesioner kesiapan untuk berubah diukur dengan empat dimensi yang dikemukakan oleh Holt et al., (2007) yaitu (1) appropriateness, (2) change efficacy, (3) management support, 
dan (4) personal valence. Uji validitas menggunakan perbandingan nilai r-hitung $>$ r-tabel dengan derajat kepercayaan sebesar $95 \%(\alpha=5 \%)$ dengan nilai r-tabel $=0,361$. Hasil uji validitas kesiapan untuk berubah mempunyai koefisien korelasi itemitem pernyataan lebih besar dari r-tabel $=$ 0,361, maka item-item pernyataan adalah valid. Pengujian reliabilitas menggunakan Cronbach Alpha ( $\alpha)$. Cronbach Alpha Pada kesiapan untuk berubah sebesar 0,864 , ini menandakan instrumen penelitian reliabel dan item-item pernyataan memiliki kelayakan untuk dijadikan alat ukur penelitian.

Alat ukur kinerja karyawan menggunakan lima indikator yang dikemukakan Mathis \& Jackson (2015) yaitu (1) kuantitas (quantity of work), (2) kualitas (quality of work), (3) ketepatan waktu (timeline of work), (4) kehadiran (attendance), dan (5) kerjasama (ability to cooperate). Uji validitas menggunakan perbandingan nilai $r$-hitung > r-tabel dengan derajat kepercayaan sebesar $95 \%(\alpha=5 \%)$ dengan nilai $r$-tabel $=0,361$. Hasil uji validitas kinerja karyawan mempunyai koefisien korelasi item-item pernyataan lebih besar dari $r$-tabel $=0,361$, maka item-item pernyataan adalah valid. Pengujian reliabilitas menggunakan Cronbach Alpha (a). Cronbach Alpha kuesioner kinerja karyawan $=0,846$, ini menandakan instrumen penelitian reliabel dan item-item pernyataan memiliki kelayakan untuk dijadikan alat ukur penelitian.

Analisis Data

Analisis data penelitian menggunakan metode Multiple Linear Regression dengan bantuan analisis program IBM SPSS Statistics 23 for Windows. Metode ini digunakan untuk menguji dan mengetahui pengaruh antara adversity quotient, komitmen organisasi dan kesiapan untuk berubah terhadap kinerja karyawan.

\section{Hasil}

Hasil Analisis Deskriptif Data

Tabel 1. Hasil Analisis Deskriptif Data

\begin{tabular}{lccc}
\hline \multicolumn{1}{c}{ Indikator } & Rata $^{2}$ & TCR (\%) & Ket. \\
\hline Adversity quotient & 3,72 & 74,4 & Cukup Baik \\
Komitmen organisasi & 3,56 & 71,3 & Cukup Baik \\
Kesiapan untuk berubah & 3,72 & 74,4 & Cukup Baik \\
Kinerja karyawan & 3,61 & 72,3 & Cukup Baik \\
\hline
\end{tabular}

Hasil riset menunjukkan nilai TCR variabel adversity quotient $=74,4 \%$, komitmen organisasi $=72,3 \%$, kesiapan untuk berubah $=74,4 \%$ dan kinerja karyawan $=72,3 \%$. Ini berarti adversity quotient, komitmen organisasi, kesiapan untuk berubah dan kinerja karyawan swalayan di Kota Padang saat ini berada pada kategori cukup baik perlu untuk ditingkatkan lagi.

\section{Hasil Uji Asumsi Klasik}

\section{Uji Normalitas}

Data dikatakan normal apabila nilai $p$ $>0,05$. Hasil uji normalitas yang dilakukan menggunakan uji KS-Z (Test Statistic) $=0,606$ dan Asymp. Sig. (2-tailed) $=0,856>0,05$, yang berarti nilai residual berdistribusi normal.

\section{Uji Multikolinearitas}

Pengujian multikolinearitas dapat diamati melalui nilai VIF dengan syarat $\mathrm{VIF}<10$, maka dapat dikatakan tidak terjadi multikolinearitas. Hasil menunjukkan nilai tolerance adversity quotient yaitu 0,293, komitmen organisasi yaitu 0,399 dan kesiapan untuk berubah yaitu 0,264 . Nilai VIF adversity quotient yaitu 3,413 , komitmen organisasi yaitu 2,509 dan kesiapan untuk berubah yaitu 
3,784. Dari hasil diketahui nilai tolerance > 0,10 , VIF $<10$, maka masalah multikolinearitas tidak ditemukan pada penelitian.

\section{Uji Heteroskedastisitas}

Uji Heteroskedastisitas dilakukan untuk mendeteksi terjadi atau tidaknya ketidaksamaan variance residual pada model regresi, dimana dasar analisis yang digunakan terdiri dari dua asumsi, yakni pertama, apabila terbentuk pola tertentu yang menggambarkan titik-titik dengan pola yang teratur itu mengindikasikan telah terjadi Heteroskedastisitas. Kedua, apabila pola terlihat membentuk titik-titik yang tersebar di atas dan di bawah angka 0 di sumbu $Y$ dan membentuk pola yang tidak jelas itu mengindikasikan tidak ada masalah Heteroskedastisitas.

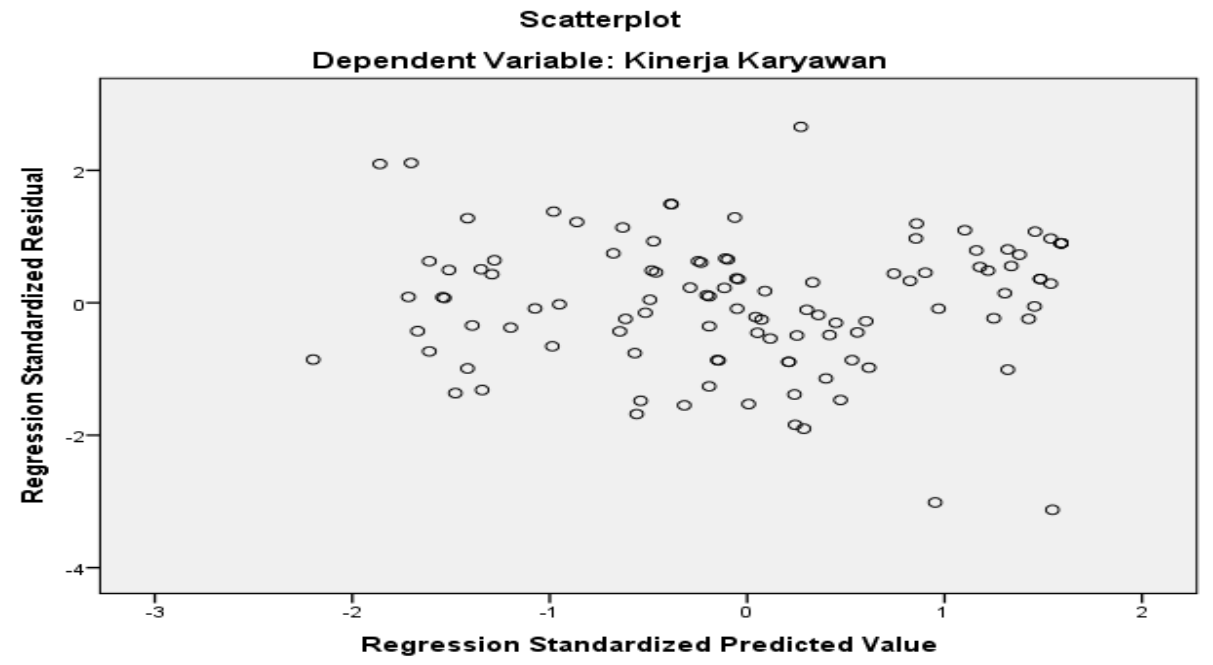

Gambar 2. Hasil Uji Heteroskedastisitas

Dari gambar terlihat titik-titik menyebar pada sumbu $\mathrm{Y}$ di atas dan di bawah angka 0 , membentuk pola yang tidak jelas mengindikasikan tidak terjadinya Heteroskedastisitas atau tidak ada kesamaan varian antar variabel penelitian.

\section{Uji Linearitas}

Uji linearitas digunakan untuk mengetahui apakah distribusi data penelitian yaitu variabel kinerja karyawan, adversity quotient, komitmen organisasi, dan kesiapan untuk berubah mempunyai hubungan linear uji $F$ (Anova). Variabel kinerja karyawan, adversity quotient, komitmen organisasi, dan kesiapan untuk berubah dikatakan memiliki hubungan linear jika $p<0,05$. Hasil uji linearitas pada penelitian menunjukkan nilai signifikansi yaitu 0,000 maka $p<0,05$, dapat disimpulkan bahwa keempat variabel memiliki hubungan linear.

\section{Hasil Uji Hipotesis}

Uji hipotesis memakai teknik penelitian analisis regresi linier berganda. Hasil hipotesis mayor diperoleh terdapat pengaruh signifikan adversity quotient, komitmen organisasi dan kesiapan untuk berubah terhadap kinerja karyawan yang dinyatakan dengan nilai F-hitung > F-tabel $(63,383>3,08)$ dan $p=$ $0,000(0,000<0,05)$, yang artinya semakin tinggi adversity quotient, komitmen organisasi dan kesiapan untuk berubah, akan semakin meningkat kinerja karyawan Swalayan di Kota Padang. Selanjutnya nilai Adjusted $R$ Square $\left(R^{2}\right)=0,636$, artinya sumbangan efektif variabel adversity quotient, komitmen organisasi dan kesiapan untuk berubah sebesar 63,6 persen terhadap kinerja karyawan dan sisanya 36,4 persen dipengaruhi faktor lain yang tidak diteliti. 
Tabel 2. Hasil Uji F

\begin{tabular}{llccc}
\hline Model & F & Sig. & Keterangan \\
\hline 1 & 63,383 & 0,000 & $\begin{array}{c}\text { Berpengaruh } \\
\text { signifikan }\end{array}$ \\
Regression & & & \\
Residual & & & \\
\hline
\end{tabular}

Hasil analisis minor pada penelitian dapat disimpulkan.

1. Terdapat pengaruh positif dan signifikan antara adversity quotient terhadap kinerja karyawan dengan nilai t-hitung $>$ t-tabel $(2,485>1,982)$ dan $p=0,015$ $<$ alpha $(0,05)$ dan $\beta=0,311$ artinya hipotesis diterima $\left(\mathrm{H}_{1}\right)$.

2. Terdapat pengaruh positif dan signifikan antara komitmen organisasi terhadap kinerja karyawan dengan nilai t-hitung $>$ t-tabel $(2,147>1,982)$ dan $p=0,034$ $<$ alpha $(0,05)$ dan $\beta=0,259$ artinya hipotesis diterima $\left(\mathrm{H}_{2}\right)$.

3. Terdapat pengaruh positif dan signifikan antara komitmen organisasi terhadap kinerja karyawan dengan nilai t-hitung $>$ t-tabel $(3,536>1.982)$ dan $p=0,001$ $<$ alpha $(0,05)$ dan $\beta=0,484$ artinya hipotesis diterima $\left(\mathrm{H}_{3}\right)$.

Tabel 3. Hasil Uji t

\begin{tabular}{lcccc}
\hline \multicolumn{1}{c}{ Model } & $\boldsymbol{\beta}$ & $\mathbf{t}$ & Sig. & Keterangan \\
\hline Constant & 6,456 & 2,859 & 0,005 & \\
Adversity Quotient & 0,311 & 2,485 & 0,015 & Berpengaruh \\
Komitmen Organisasi & 0,259 & 2,147 & 0,034 & Berpengaruh \\
$\begin{array}{l}\text { Kesiapan Untuk } \\
\text { Berubah }\end{array}$ & 0,484 & 3,536 & 0,001 & Berpengaruh \\
\hline
\end{tabular}

\section{Pembahasan}

Hasil penelitian ini membuktikan bahwa adversity quotient mempengaruhi kinerja karyawan. Empat dimensi adversity quotient yaitu kendali (core), asal usul dan pengakuan (origin dan ownership), daya jangkauan (reach), dan daya tahan menghadapi kesulitan (endurance) ada pada kategori cukup baik. Indikator yang memiliki pengaruh paling dominan yaitu daya tahan menghadapi kesulitan (endurance) atau dapat diartikan bahwa rata-rata karyawan sudah memiliki daya tahan namun belum memaksimalkannya dengan baik. Karyawan memiliki inisiatif, semangat dan usaha menghadapi situasi pandemi Covid-19, namun belum mampu memaksimalkannya sampai batas kemampuannya. Hasil penelitian sesuai dengan hasil penelitian sebelumnya yang menyatakan bahwa adversity quotient berperan penting bagi karyawan untuk meningkatkan kinerjanya (Runtu et al., 2019). Hasil penelitian Wolor et al., (2020) juga menunjukkan bahwa terdapat pengaruh adversity quotient terhadap kinerja karyawan. Dalam penelitiannya dijelaskan bahwa pentingnya perusahaan mengadopsi adversity quotient bagi karyawan dengan melatih karyawan terutama membimbing, memberikan ruang yang fleksibel untuk mengambil keputusan dan mengeksplor kapabilitas diri dalam mencapai target kinerja yang ditetapkan perusahaan. Adversity quotient setiap orang yang berbeda menyebabkan perbedaan pula pada kinerja 
(Hastuti et al., 2018).

Penelitian ini tidak sejalan dengan penelitian Ablaña et al., (2016) yang membuktikan adversity quotient bukanlah konsep yang mampu meningkatkan kinerja, artinya adversity quotient tidak menentukan bagaimana kinerja karyawan di tempat kerja. Sedangkan hasil penelitian yang dilakukan (Lubis, 2019; Irawan \& Yulihasri, 2019; Setiaji \& Herminingsih, 2015) mengemukakan bahwa terdapat pengaruh signifikan adversity quotient terhadap kinerja. Menurut Listiawati \& Sebayang (2019), semakin aman, nyaman dan tinggi kepercayaan karyawan, maka semakin tinggi adversity quotientnya dapat memberikan dampak pada kinerja karyawan. Hal ini sejalan dengan penelitian Phoolka \& Kaur (2012) bahwa kemampuan seseorang untuk mengatasinya situasi sulit akan berdampak pada peningkatan kinerja karyawan.

Penelitianinijugamemperoleh hasilbahwa komitmen organisasi mempengaruhi kinerja karyawan. Pada penelitian ini ditemukan bahwa komitmen organisasi ditentukan oleh komponen komitmen afektif, komitmen normatif serta komitmen berkelanjutan yang berkontribusi signifikan terhadap kinerja. Dengan memiliki komitmen yang kuat, karyawan akan didorong untuk bekerja keras dalam mencapai kemajuan dan tujuan yang diinginkan. Kinerja karyawan berkualitas tinggi dicapai melalui komitmen organisasi secara langsung atau berkelanjutan. Penelitian ini konsisten dengan penelitian Paramita et al., (2020) menyatakan bahwa terdapat pengaruh positif komitmen organisasi terhadap kinerja karyawan. Dalam penelitiannya dijelaskan bahwa komitmen organisasi karyawan berasal dari komitmen afektif dan komitmen kontinuitas. Kedua aspek ini memberikan kontribusi signifikan terhadap kinerja. Hasil ini sejalan pula dengan penelitian Fakhruddin et al., (2020). Hasil penelitian menunjukkan bahwa komitmen organisasi memberikan pengaruh positif dan signifikan terhadap kinerja yang berarti semakin baik komitmen organisasi, maka kinerja akan meningkat dan pengaruhnya akan bermakna.

Menurut Chidir et al., (2020), seseorang yang bangga menjadi anggota organisasi, menjaga nama baik organisasi, peduli dengan nasib organisasi, terikat secara emosional, bekerja atas kemauan dan dorongan dari diri sendiri, membutuhkan pengorbanan pribadi, sulit keluar dari organisasi, bekerja sesuai dengan jam kerja yang ada, berani mengambil resiko, bekerja dengan keahlian yang sesuai memiliki pengaruh signifikan terhadap kinerja. Menurut Rais et al., (2016) kinerja akan meningkat apabila dilakukannya perbaikan komitmen organisasi pada karyawan. Hasil penelitian Ratnasari et al., (2020) membuktikan bahwa komitmen organisasi berpengaruh signifikan terhadap kinerja.

Hasil penelitian membuktikan pula bahwa kesiapan untuk berubah mempengaruhi kinerja karyawan. Hasil riset variabel kesiapan untuk berubah menemukan bahwa dimensi appropriateness, appropriateness, change efficacy, management support dan personal valence berada pada kategori cukup baik. Indikator yang paling dominan berpengaruh yaitu appropriateness, dimana pegawai meyakini bahwa perubahan diperlukan bagi kemajuan organisasi dan meyakini pula perubahan akan memberi keuntungan bagi organisasi. Karyawan merasa perubah akan sesuai dengan prioritas dari organisasi serta meningkatkan efisiensi organisasi.

Menurut Kamar et al., (2020) keyakinan karyawan dan semangat kesiapan untuk berubah dapat mempertahankan kinerja yang baik. Menurut Kustini et al., (2020) menyatakan kesiapan untuk berubah berperan penting dalam menentukan tinggi rendahnya kinerja. Hasil riset sejalan juga dengan penelitian Novitasari et al., (2020). Hasil penelitian ini membuktikan bahwa terdapat pengaruh positif dan signifikan kesiapan untuk berubah terhadap kinerja karyawan. 
Selain itu, penelitian lain yang dilakukan oleh Banjongprasert (2017); Katsaros et al., (2020) menunjukkan terdapat pengaruh positif dan signifikan kesiapan untuk berubah terhadap kinerja.

Berdasarkan penjelasan di atas maka dapat dikatakan adversity quotient, komitmen organisasi, dan kesiapan untuk berubah dapat meningkatkan kinerja karyawan pada situasi pandemi Covid-19. Sehingga dapat disimpulkan bahwa terdapat pengaruh signifikan adversity quotient, komitmen organisasi, dan kesiapan untuk berubah terhadap kinerja karyawan. Semakin tinggi adversity quotient, komitmen organisasi, dan kesiapan untuk berubah, maka semakin tinggi kinerja karyawan, dan sebaliknya semakin rendah adversity quotient, komitmen organisasi, dan kesiapan untuk berubah yang dimiliki maka semakin rendah kinerja yang dimiliki karyawan.

\section{Kesimpulan}

Berdasarkan hasil riset, dapat disimpulkan bahwa terdapat pengaruh antara adversity quotient, komitmen organisasi dan kesiapan untuk berubah terhadap kinerja karyawan. Implikasi dari penelitian ini bagi perusahaan dan praktisi psikologi dalam industri dan organisasi diharapkan mampu membangkitkan adversity quotient karyawan sehingga memiliki daya tahan saat menghadapi kesulitan dalam situasi apapun. Selain itu, komitmen organisasi perlu ditingkatkan karena dengan komitmen yang kuat karyawan akan terdorong lebih bekerja keras dalam mencapai tujuan yang diinginkan. Sosialisasi berbentuk pelatihan perlu dilakukan agar karyawan lebih siap dalam menerima perubahan sehingga kinerja akan lebih optimal.

\section{Daftar Pustaka}

Abdullah, M. (2014). Manajemen dan Evaluasi Kinerja Karyawan. Aswaja Pressindo.
Ablaña, M. V. V, Isidro, D. J., \& Gino A. Cabrera, M. (2016). Correlation between adversity quotient and job performance of Igu employees of Tayabas City : input to effective public personnel management. Journal of Research of the College of Arts and Sciences, Southern Luzon State University, Lucban, Quezon, PH, 8(2), 109-122.

Ariyanto, A., Pono, M., \& Munir, A. R. (2019). The influence of organisational culture, motivation, and organisational commitment on employee performance. Hasanuddin Journal Of Business Strategy, 1(3), 79-87. https://doi.org/10.26487/ hjbs.v1i3.255.

Asbari, M., Novitasari, D., \& Goestjahjanti, F. S. (2020). Mempertahankan kinerja karyawan di masa pandemi COVID-19: studi kasus pada industri ritel. JMK (Jurnal Manajemen Dan Kewirausahaan), 5(3), 183-203.

Azwar, S. (2015). Penyusunan Skala Psikologi. Pustaka Belajar.

Bacal, R. (2015). Performance Management. PT. Garmedia Pustaka Utama.

Banjongprasert, J. (2017). An assessment of change-readiness capabilities and service innovation readiness and innovation performance: empirical evidence from MICE Venues. IJEM International Journal of Economics and Management, 11, $1-7$.

Chidir, G., Fayzhall, M., Sopa, A., Mustikasiwi, A., Asbari, M., \& Purwanto, A. (2020). The role of organizational commitment, organizational culture and mediator organizational citizenship behavior (OCB) on employees' performance: Evidence from Indonesian automotive industry. International Journal of Control and Automation, 13(2), 615-633.

Fakhruddin, F., IImi, Z., \& Achmad, G. N. (2020). The influence of personality and organizational commitment and work engagement to employee satisfaction and employee performance DPRD Samarinda city. International Journal of Economics, Business and Accounting Research (IJEBAR) Peer, 4(2). 
Fattah, H. (2017). Kepuasan Kerja dan Kinerja Pegawai, Budaya Organisasi, Perilaku Pemimpinan dan Efikasi Diri. Elmatera.

Hastuti, T. D., Sari, D. R., \& Riyadi. (2018). Student profile with high adversity quotient in math learning. Journal of Physics, 983(1).

Hendri, M. I. (2019). The mediation effect of job satisfaction and organizational commitment on the organizational learning effect of the employee performance. International Journal of Productivity and Performance Management, 68(7), 27.

Holt, D. T., Armenakis, A. A., Feild, H. S., \& Harris, S. G. (2007). Readiness for organizational change: the systematic development of a scale. The Journal of Applied Behavioral Science, 43(2).

Irawan, W., \& Yulihasri. (2019). Effect of adversity quotient, motivation and discipline on the performance of employees PT. PLN (Persero) West Sumatra Padang Indonesia. International Journal of Innovative Science and Research Technology, 4(4), 564-568.

Kamar, K., Novitasari, D., Asbari, M., Winanti, W., \& Goestjahjanti, F. S. (2020). Enhancing employee performance during the COVID-19 pandemic: the Role of readiness for change mentality. Jurnal Dinamika Manajemen, 11(2), 154-166. https://doi.org/10.15294/jdm. v11i2.25279.

Katsaros, K. K., Tsirikas, A. N., \& Kosta, G. C. (2020). Impact of leadership on firm financial performance: the mediating role of employees' readiness to change. Leadership Dan Organization Development Journal, 41(3), 333-347.

Kristian, B., \& Ferijani, A. (2020). The effect of job satisfaction and organizational commitment on employee performance with ocb as the intervening variables (a case study on PT. Ulam Tiba Halim Distributor Company). Journal of Management and Business Environment (JMBE), 2(1), 1-21.

Kustini, Izaak, W. ., \& Rini, H. . (2020). Pengaruh kesiapan untuk berubah dan proactive behavior terhadap kinerja. Jurnal
Bisnis Dan Manajemen, 14(3), 180-190. Listiawati, N., \& Sebayang, S. K. (2019). The association between sociodemographic factors and teachers' guidance towards students' adversity quotient. International Journal of Education, 11(2), 109-116.

Lubis, A. S. (2019). The influence of adversity quotient and job stress on employee performance through work motivation as an intervening variable (Study of conventional taxi drivers in Medan City). Management and Economics Journal (MECJ), 3(2), 182. https://doi.org/10.18860/ mec-j.v3i2.6312.

Mathis, R., \& Jackson, J. (2015). Manajemen Sumber Daya Manusia. Salemba Empat. Meilina, R., \& Sardanto, R. (2020). Dampak perubahan lingkungan kerja non fisik masa pandemi COVID-19 bagi karyawan toserba barokah kota Kediri. Penelitian Manajemen Terapan (Penataran), 5(1), 46-56.

Meyer, J. P., \& Allen, N. J. (1997). Commitment in The Workplace: Theory Research and Application. Sage Publication.

Moeheriono. (2012). Pengukuran Kinerja Berbasis Kompetensi. Raja Grafindo Persada.

Novitasari, D., Asbari, M., Rizky Wijaya, M., \& Yuwono, T. (2020). Effect of organizational justice on organizational commitment: mediating role of intrinsic and extrinsic satisfaction. International Journal of Science and Management Studies (IJSMS), June, 96-112. https://doi. org/10.51386/25815946/ijsms-v3i3p110. Paramita, E., Lumbanraja, P., \& Absah, Y. (2020). The influence of organizational culture and organizational commitment on employee performance and job satisfaction as a moderating variable at $\mathrm{PT}$. Bank Mandiri (Persero), Tbk. International Journal of Research and Review (ljrrjournal.Com), 7(March),3.https://www. ijrrjournal.com/IJRR_Vol.7_Issue.3_ March2020/ IJRR0037.pdf.

Phoolka, S., \& Kaur, N. (2012). Adversity quotient: a new paradigm to explore. International Journal of Contemporary 
Business Studies, 3(4), 67-78.

Rais, R., Adolfini, D., \& Dotulong, L. (2016). Komitmen organisasi, kepuasan kerja dan lingkungan kerja terhadap kinerja karyawan di PT. PLN (Persero) Wilayah Suluttenggo. Jurnal Berkala IImiah Efisiensi, 16(1).

Ratnasari, S. L., Widiyah Nasrul, H., Nurdin, I., Susilowati, Y., \& Manurung, S. (2020). Employee performance: organizational commitment, motivation, work ability, and work environment. International Journal of Advance Science and Technology, 29(10), 1074-1084.

Rohmah, S. N., \& Syari, F. (2020). Adakah peluang bisnis di tengah kelesuan perekonomian akibat pandemi coronavirus COVID-19? 'adalah'. Buletin Hukum Dan Keadilan, 4(1), 63-74. https://doi. org/10.15408/adalah.v4i1.15448.

Runtu, D., Aldrin, N., \& Merdiaty, N. (2019). Effect of work ethics on job performance with adversity quotient as a mediator. International Journal of Research in Business and Social Science (2147- 4478), 8(5), 98-103. https://doi.org/10.20525/ ijrbs.v8i5.457.

Setiaji, H., \& Herminingsih, A. (2015). Pengaruh adversity quotient dan learning organization terhadap kinerja karyawan Pusdiklat. BISMA (Bisnis Dan Manajemen), 7(2), 73-80.

Stoltz, P. G. (2005). Adversity Quotient : Mengubah Hambatan Menjadi Peluang. PT. Grasindo.

Thaha, A. F. (2020). Dampak COVID-19 terhadap UMKM di Indonesia. Jurnal Lentera Bisnis, 2(1), 147-153. https://ejournals.umma.ac.id/index.php/brand.

Wibowo. (2012). Manajemen Kinerja. PT. Raja Grafindo Persada.

Wolor, C. W., Pratama, A., Aditya, S., Fadillah, N. F., \& Purwana, D. (2020). Adversity quotient in improving millennial generation salespeople's performance in the industrial revolution 4.0. Humanities \& Social Sciences Reviews, 8(1), 220-226. 